\title{
Caribbean Indigenous Experiences of Erasure: Movement, Memory and Knowing
}

\author{
Experiencias indígenas caribeñas \\ de movimiento de borrado, \\ memoria y conocimiento
}

\section{ERICA NEEGANAGWEDGIN}

Ph.D. in Education

Western University, Canada https://orcid.org/0000-0001-6131-1812 Email: ericaneegan@yahoo.ca

Cómo citar este

artículo en APA:

Neeganagwedgin

$\mathrm{E}_{l}$ (2022). Caribbean

Indigenous Experiences

of Erasure: Movement,

Memory and Knowing.

Analecta Política, 12(22),

1-17. doi: http://dx.doi.

org/10.18566/apolit.

v12n22.a01

Fecha de recepción:

21.09.2021

Fecha de aceptación:

15.12.2021 


\section{Abstract}

The Caribbean world has experienced a centuries-long process of European expansion into their territories. This article outlines the dramatic impact and disruption due to colonization and imperialism, and the ways in which these interlocking systems have shaped contemporary Taino understandings. It examines what it means to remember our Taino ancestors, their histories that persist and are embedded in the fabric and landscape of everyday Caribbean memories, their culture, and their lifeways that permeate many Caribbean names, places, and lands. This paper examines memory discourse and knowledge as ways and enactments of embodied Taino presence and contemporary life.

Keywords: Taino Caribbean Indigenous; Sovereignty; Self Determination; History.

\section{Resumen}

El mundo caribeño ha experimentado un proceso de siglos de expansión europea en sus territorios. Este artículo describe el impacto dramático y la interrupción debido a la colonización y el imperialismo, y las formas en que estos sistemas entrelazados han dado forma a la comprensión del mundo taíno contemporáneo. Examina lo que significa recordar a nuestros antepasados taínos, sus historias que persisten y están incrustadas en el tejido y el paisaje de las memorias caribeńas cotidianas, su cultura y sus formas de vida que impregnan muchos nombres, lugares y tierras caribeños. Este artículo examina, además, el discurso de la memoria y el conocimiento como formas y actuaciones de la presencia taína encarnada y la vida contemporánea.

Palabras clave: Taíno; Caribe Indígena; Soberanía; Autodeterminación; Historia. 


\section{Introduction \& Background}

Taino Peoples in the Caribbean are the First Peoples in what is known as the western hemisphere to experience the full impact of colonization (Curet 2002). According to Reynoso (2017 para 1), Taino People of Hispaniola (known now as Haiti and the Dominica Republic) were among the first to experience the devastation of Spanish imperialism and exploitation due to the creation of the white supremacist empire. Smith (2012 p. 57) asserts that imperialism still hurts and continues to destroy while continuously reinventing itself. The Caribbean became the site of Europe's first external industries, starting in the sixteenth century (Yelvington 2000 para 1).

Taino cultures and Peoples flourished before the 1400's. Wesley-Esquimaux, in examining the devastation which occurred after 1492, explains how, beginning in the late 1400s, Indigenous Peoples faced "severely depressing experiences generation after generation related to massive depopulation, unchecked murder and warfare, destroyed social structures and disempowered spiritual authorities and supports" (Wesley-Esquimaux 2007 p. 8). Concerning Caribbean Indigeneity, everyone but Taino People have written about Indigenous Peoples of the Caribbean for more than 500 years, reinforcing a discourse of their non-existence from their lands. This story has been prevalent for centuries and has become normalized and consistent. Forte (2006 p. 46) explains that this discourse is taken for granted and is seen as non-problematic. Salis Reyes (2018 p. 748) also speaks about colonialism as being prevalent, bringing normalcy to these accounts.

Forte (2006 p. 47) argues that recognizing the existence of Indigenous Peoples of the Caribbean contradicts long-held beliefs of the history of the area. Assumptions of their extinction make any mention of their Indigeneity to be questioned. It is a historical fact that Taino People experienced and endured genocide, yet many managed to continue. It is often forgotten that these global processes began with the European expansion into the Caribbean more than five hundred years ago (Yelvington 2000 para 1). Mentioning the year 1492 is often detached from the Taino People, from the Caribbean, and from the concept of their Indigeneity. The genocide occurred, yet Indigenous Peoples of the Caribbean have largely been forgotten given the devastation which their ancestors experienced and the impact which endures.

Powell and Peristerakis (cited in Jones 2017 p. 27) provide a framework for the understanding of genocide to contextualize its use in relation to Taino People. They state that "We define genocide as the violent erasure of a collective identity 
and understand genocide as a multidimensional process that works through the destruction of the social institutions that maintain collective identity as well as through the physical destruction of human individuals." Despite the genocide which Indigenous Peoples of the Caribbean continue to experience, they are not fixed in time and they exist in the present. Silliman (cited in Henry \& Woodward 2019 p. 96) describes the dominant 'fatal impact model' as a misconception. The idea of the sudden devastation of Taino People is erroneous. Currently, the understanding of Taino Peoples' right to their peoplehood and to exist often goes unchallenged. Recent research illustrates that Taino People used and developed strategies and approaches in defiance of the conditions which were imposed upon them (see Henry \& Woodward 2019).

In an analysis of Indigenous Rights and recognition in the Eastern Caribbean, Strecker (2016, p.167) discusses the use of the assertion of Indigenous nonexistence to legitimize appropriating Indigenous Lands, and she adds that "these misconceptions have been put under increasing scrutiny, not only by archaeological, historical, and ethnographic research but also, more importantly, by communities themselves." Taino communities throughout the Caribbean are asserting themselves and demonstrating their survivance, natural rights and sovereignty.

As I engaged in writing this paper, I found only a few stories which were written from Taino perspectives. Nevertheless, Taino communities are speaking, both quietly and loudly, and sharing their experiences. Salis Reyes (2018 p. 752) suggests, from the Hawai'ian context, that "for far too long, others have tried to tell stories about who we are and where we belong. These narratives have been pervasive, and yet we have resisted." It is not uncommon for Indigenous peoples globally to experience similar forms of systemic displacement. Nor is it uncommon for Indigenous communities' stories to be erased physically and through forms of colonial laws.

This paper draws on the historical context and experiences of Taino People. More specifically, it centers the worldviews of Yamaye (Jamaica) Taino People. It discusses issues which demonstrate the ways in which they have established ingenious and sustainable ways to practice their lifeways today. This paper presents the history of Taino People to contextualize their experiences. It examines the themes of blood, memory, land and body in relation to Taino sovereignty, and it examines Taino Peoples' resurgence and re-emergence in present times. 


\section{Methodological Consideration}

The methodological consideration for this work involves everyday lived experiences and stories. I remember preparing for a recent presentation which I titled my Yamaye identity and community. When I used the PowerPoint to generate graphic designs, the heart-shaped symbol signifying love came up. I thought to myself that even my computer software knows how much being Taino is heart work to me. "What is in the heart, the centre can be the most personal, intimate, or even sacred knowledge one stewards" write Hernandez et al. (2018 p.162). Loving Taino means loving the ancestors and embodying them. In writing about erasure of Taino Peoples, I also write about Taino agency, because in the present time, Taino People have transcended the usual everyday stories of their nonexistence. This paper takes on a methodological framework of Indigenous stories and philosophies as a way of living. H. Smith (2019 p.3) explains how "planting a garden, or engaging in being a mother to our children, are forms of "methodology" which is informed by our experiences and knowledge, values and beliefs, societal influences, and so on." Archibald (2008) refers to this as story memory pathway.

I draw on literature which ensures that multiple voices, and Taino perspectives and worldviews, are presented to help to understand Taino Peoples' present-day context. Story centering as a methodology helps to frame Taino experiences historically and links them to the current context. This methodological framework also focuses on Indigenous and Taino "theories of knowledge" (Porsanger, J. et al. 2021 p. 167), approaches and experiences. I choose to focus on stories, including those shared with permission from my mother, and stories and analyses which emerge and remerge in the literature and discussion. Many Indigenous scholars refer to this as restorying (see Archibald 2008; Smith 2012). As H. Smith (2019 p. 10) writes, Indigenous Methodologies help us to think about and understand the world through lived experiences. This understanding has existed for thousands of years. This approach to the literature frames the following discussion that represents multiple, distinct, and unique lenses including Taino perspectives. One common theme that can be drawn from these multiple contexts is the understanding of decolonial work in the production of these knowledges. This methodological framework encompasses historical lenses of the Taino world to understand Taino Peoples' contemporary situatedness. 


\section{Taino Peoples and Historical context}

Europeans reached the Island of Yamaye (Jamaica) in 1494. On reaching the Island, they declared it to be their own. They returned to the Island in 1504 and lived there for a year after their ship malfunctioned (see Flint para 3). This claim to Taino ancestral lands aligns with the European world view of the empty lands (terra nullius) belonging to no one. In fact, a central feature of European colonialism in Latin America (as one example) was the assertion of crown ownership of Indigenous lands (see Rousseau \& Rousseau 2018 p.59). This occurred not only in Latin America but also globally, and it is more than a small historical detail. For example, terms such as "founding fathers" highlight the sense of entitlement and possessiveness which led to the systemic violence and attempted elimination of Indigenous Peoples.

While the objective of this paper is not to center colonizers, it is difficult to refrain from speaking about the history of genocide. It is through writing that the voices and stories of my ancestors and their survivance are remembered and magnified. Harkin (2014) describes memory as the result of remembering, and it is framed through the retrieving of data that comes from lived experiences and knowledge systems.

Taino voices throughout the Caribbean and in Yamaye have been suppressed for years. To make sense of Taino Peoples' experiences, and to understand Indigeneity in a Caribbean context, including Taino sovereignty in action, the historical insights into the systemic brutality and the ways in which they navigate and negotiate the circumstances they found themselves in must be contextualized. Taino people in Yamaye demonstrated defiance against colonizers (see Gardner 2020).

Throughout Yamaye, many caves were seen as sacred by Taino ancestors, and some were used as burial sites. Taino People have used resourceful ways, with their understanding of their ancestral landscape, to find refuge in the Island. The land itself, Earth Mother Atabei, was their protector. Europeans could not believe their eyes at the large number of Indigenous People throughout the Island (see Gardner 2020). This made Yamaye one of the most flourishing Islands with large populations of Indigenous peoples, from coast to coast to Inland and through and through.

Delucia, Kiel, Philips and Vigil (2021 para. 4) state that the writing and teaching of history is closely linked to the processes of power and subjugation of Indigenous Peoples. It is important not to forget this history. Bogado (2015) 
observed that "The wealth from resources like sugar, tobacco, and cotton ushered in the start of the Industrial Revolution, which began emitting carbon at an unprecedented record level." Further, "colonization did not just heavily impact the people, but the very lands which sustained them. The sacred relationship was brutally disrupted and subsequently replaced over centuries by a mainstream acceptance of patriarchal dominion over the natural world" (Borrero 2017 para 2). Koch, Brierley, Maslin and Lewis (2019) affirm what Taino Peoples already knew that there are interconnecting systems between colonization, imperialism and the genocide Taino People experience, its impact on the land, the sea, the climate, the ecosystems and the environment.

Rivera-Santana (2017 p. 572) describes this as a realm of Western ugliness which is driven by domination. Delucia et al. (2021 para 8) speak to the thousands of years that Indigenous Peoples have their "lived experience in specific geographical locations." They continue to live their lives and build their own frameworks on the land in balanced ways informed by their ways of life. That resonates with the history of the Taino People who governed themselves on their own terms for centuries. As Rivera-Santana (2017) puts it, "Slavery was the crudest form of capture; the process of capture meant bringing ...peoples into the gaze, and therefore into the course of conceptualisation, of the colonial West" (p. 579).

Bogado (2015) warns of the danger of taking European encroachment lightly even today (2015 para 7) and highlights how these processes ignited "European imagination, and those lands would soon be the backbones of empires." Violence was central to colonial control, power, and domination over Indigenous peoples during their first contact with Europeans (Rousseau \& Rousseau 2018 p.58). The combination of capitalism, imperialism and colonialism resulted in the development of global capitalism as we know it today. This brought about many changes, shifts and movements including the exploitation of Taino resources for the socio-economic gain of European imperialist nations, the establishment of white supremacist racial hierarchies on the Caribbean islands, and patriarchy (see Reynoso 2017). The erasure of Indigenous identity and people in Jamaica happened in stages, as explained by the Island's first Kasike "Kalaan" Nibonrix Kaiman (cited in BEx 2020), and was therefore systemic and deliberate.

In an examination of the time of contact in Jamaica, Henry and Woodward (2017) write about the community of Maima and examine how Taino people were impacted. Taino People left their communities as part of their survivance. The authors also note that "In that short time, the villagers showed a resistance to the culture and influence of those colonizing them" (98). These Taino communities 
displayed expressions of their self-determination which connect with today's movement of Taino re-emergence. Indigenous opposition movements generally have challenged European acts of subjugation. These movements responded to epidemic diseases and the oppression and enslavement of community members (see Delucia et al. 2021).

Moreover, not only does Caribbean cultural production move in international orbits, but Caribbean people do, too. Movement has always been a feature of Caribbean society (Yelvington 2005 para 5). For Taino People today, movement is spiritual and, no matter where we move, the ancestors are never left behind because we carry them within.

\section{Blood, Memory, Land and Body}

For Taino People, the memories of their ancestors are always present. We carry the memories in our blood, and they are passed from generation to generation. Harkin (2014 p. 4) writes that our bodies are also archives that store our memories and lived experiences which are "etched and anchored in our bloodlines deep." Many Indigenous People experience genocide not only physically, but also on paper where they were, and still are, deliberately and systemically forced to assimilate through laws which were enforced upon them. Like many Indigenous People, the Taino People were written out of history, and this writing out informs the present. Yet, Harkins (2014 p. 4) reminds us that "these memories in our blood ground our creativity in what become personal and political acts of remembering, identity making and speaking back to the State."

Paradoxically, the colonizers' records often claim Taino "disappearance" after the European arrival and torment, but they also document Indigenous presence. Their attempts to obliterate Taino People have not been successful. Archival and other research to find answers about Taino Peoples' historical experiences often lead us back to colonial institutions and records. For example, as Europeans such as Rampini (1840) travelled to the Island of Jamaica, reports or memoirs were written to indicate that Taino People were living their lives in their communities on the Island at that time. Rampini wrote

In the great savanna of St Elizabeth's resides a curious colony of blacks whose origin has puzzled most travellers. They go by the name of Paratees and build their huts in the little clumps of bush. With which the plain is dotted...it is supposed 
that they are of Indian origin...They form a curious and by no means uninteresting problem to the ethnologist (1873 p. 160).

Tomlin-Kräftner (2020 p.82) emphasized the following: at every process and experience with European colonization, Taino People expressed their governance and challenged both Spanish and British dominance. Harkin (2014 p. 3) speaks to what it means to engage with these colonial documents in which the ancestors' voices also speak. The author describes the ancestral connection in the comment that "I longed to go right back to that beginning place . . . to those first colonial-recordings of my family, to the frontier-violence-contact-zone, and trace my blood from there. I gathered what I could. The hoarding had begun.” Today, Taino write from their own viewpoints, and instructions are given to them from the ancestors as they continue to live and tell their story. Consequently, this type of continuity is survivance (see Vieznor 1999).

Harkin tells us that blood memory is connected to community and the reclamation of language, culture and remembering. This is explained in the following comments:

Blood memory is a process which identifies a relationship to individual and collective heritage and to family and ancestors, written through the land and body: where the claiming of communal memory juxtaposed with current individual memory is a necessity; where future memory is embodied through lineage and passed on in literature ... a sifting of one's Indigenous roots through generational storytelling (Harkin 2014, p. 6).

Kennedy and Radstone (2013 p. 238) also discuss the history and the violence that has been committed against Indigenous peoples in an Australian context. They write "this particular past remembered, dis-remembered, forgotten and repressed." Taino ancestors lived on their Caribbean ancestral territories, walking the path that many of us do today. Gibson (cited in Kennedy \& Radstone 2013) talks about memory being deeply embedded in the earth and layered. When our Taino ancestors, who I call agricultural scientists, planted their sweet potato and Cassava or Yuca, this working of the land produced memory and, therefore, the ancestral lands are like a memory system (see Kennedy \& Radstone 2013, 240).

Wesley-Esquimaux (2007 pp. 7-8) claims that the way in which we remember history and everyday experiences, or the way we look at or examine our memories, can influence the present circumstances. We gain insights from our own memories that are carried through our bloodlines. Memories are stored through 
our dreams. Harkin further discusses archives, noting that "We gain insight into intimate conversations, letters, behaviours and movements, juxtaposed with categorisations of people, places, landscapes and objects. These records are our memories and lives, material, visceral, flesh and blood" (Harkin 2014 p. 4). Even from within the writings of the colonizers our ancestors speak. Their stories are present and cannot be erased. Our ancestors are in the lands. Harkin (2014 p. 5) offers these insights: "Indigenous people write to create, to survive, and to revolutionise; we write to haunt, and we ache because we refuse to leave the past alone." For Taino People, the past is understood as the present.

This worldview is supported by Kearney who states that memory is more than the past or even a present connection. Rather, it is "immediate, here and now: transcending time, instructing us in how to 'go on"” (2020 p. 165). This aligns with Pember's understanding of how our ancestors continue to guide us, and their stories are transferred within the bloodlines and are still alive. The author states how Blood memory is the ancestral connection to language, songs, spirituality, and teachings. "It is the good feeling that we experience when we are near these things" (Pember 2010 p. 2). Kearney (2020 p. 167) refers to "present memory" as a way of seeing memory as not being in, or dependent on, the past. The author explains that "This involves a conception of memory in a temporal framework that is not dependant on a referral to the past, but rather is intimately linked to the present and what lies ahead." This is significant for Taino People who live with the land and who respect our Earth Mother Atabei. We have ongoing relationships which are embedded in reciprocity. "We learned to live with what the Caribbean had to offer and make the best of it" (Ortiz Cintrón 2018 para 2). The brutality experienced by our ancestors is different from the violence that is experienced by Taino people today. Nonetheless, the institutionalized and systemic discourse on elimination continues. The identities and existence of Indigenous Caribbean People remain contested and are often scrutinized, categorized, and misplaced when they assert themselves.

Kearney writes:

If younger generations are positioned behind the ancestors, then they are already positioned behind an already existing template for memory and are yet to meet or encounter their ancestral beginnings and are yet to step forth with the required knowledge. Rather than calling on the past in the construction of memory, they are drawing on their present and what lies ahead of them and thus are generating present memories (2012 p. 169). 
As Taino people from the Caribbean, it is imperative that we continue to govern ourselves. Learning our language, celebrating our culture through ceremony and our Areitos, drawing on our Ancestral Plant and Land knowledge systems, and developing good relations are all examples of Taino governing structures which leads us into a new re-emergence of Taino peoplehood.

\section{Taino Resurgence and Re-emergence}

Salis Reyes (2018 p. 740) discusses the historicity of colonialism and its destructive, harmful impact. Yet, the author writes about the continuity of Kānaka Maoli despite the history of violence, and notes in relation to Hawai' $i$ that "Our (hi)stories are (hi)stories of strength." Although many stories about Indigenous Caribbean People reinforce their invisibility, Strecker (2016) shows how communities have gained progress by challenging normalized narratives and re-centering some of the 'cultural and political' spaces which had been denied to them previously. This is true of many Indigenous communities in the Caribbean, including the Yamaye Taino People.

Similarly, Strecker's analysis of Indigenous Peoples in Trinidad shows that the removal from official records does not represent their reality because some Indigenous Peoples continue to practice their cultural traditions and identify with their Indigenous identity (2016 p.174). These are examples of incredible forms of resurgence and Indigenous self-determination in action. Strecker's findings are also applicable to the Yamaye context. As my research demonstrates (see Neeganagawedgin 2015), many communities and people in Yamaye continue to practice their Taino ways. One element that was explicitly notable and different is that, while they engage in Taino cultural continuity, many do not necessarily openly identify as Taino. This could be partly because of the extinction discourse, and Taino People are often denounced when they challenge the status in quo. These imaginings of Taino death are often formed, produced, socialised, maintained and reproduced (Rivera-Santana 2017 p. 579).

Yet, in Yamaye (Jamaica) many Taino food practices continue. This demonstrates Taino cultural lifeways and identity across the Island. The previously mentioned Cassava or Yuca, for instance, has always been a special food source for our family and our community. In fact, there is a spirit of happiness in knowing that you have Cassava as an available food source. Recently, it did not come as a surprise when my mother was planning a visit to my ancestral homeland and 
told me that she was taking twenty bammy bread made from Cassava with her. Interestingly, I did not need to wonder why my mother was taking Cassava with her when Cassava is readily available and plentiful there. Even more, on arrival, all community members and family offered bammy when my mother visited with them. This speaks to the significance of Cassava and indicates that it is more than just food. Cassava was an integral food source for Taino ancestors, and it remains that way today. It signifies a connection to being Taino; an attachment and relationship with the ancestors, and, of course, spirituality. It is sustainable and continues to provide food sovereignty and security in many communities across the island. Rivera (2010 para 2) examines its importance further, stating that Taino People "referred to their homes as "Yucayeques," referring to the place where Yuca is grown." The author describes Cassava/Yuca as a gift to the people. I am grateful for these relationships with Yuca, with the ancestors, with the lands where the Yuca grows and the communities that continue to plant Cassava and share with each other all over the beautiful Island.

Despite continued stories and mired contradictions of Taino Peoples frame in the past, there seems to be a shift, and increasing numbers of Yamaye Taino people are identifying, resulting in a regeneration among Taino communities and a subversion of the dominant discourses. Charles and Cajete (2020 p. 68) call for the reassertion of Indigeneity by Indigenous people, and an understanding of ancestral lands and a rebuilding of that relationship. Building the relationship with the land affirms and honours ancestral knowledge systems. Rivera-Santana (2019 p 2) explains, from a Taino and Indigenous worldview, the understanding that asserting "We are still here" offers a Taino worldview which reflects the belief that "Time, life, death and humans are not separable entities from each other; they are intricately entangled, not just connected."

Due to the impact of colonialism and imperialism on many Indigenous people, be it in different ways around the world, the last thirty years have seen "the strengthening and re-emergence of Indigenous groups around the globe" (Durán Matute 2021 p. 257). In the work being done as Yamaye Taino, we aim to recover and retell (Rousseau \& Rousseau 2018 p. 179).

Like the experiences of Taino People, Salis Reyes (2018 p. 740) discusses reemergence, remarking that "I am proud to be Hawaiian. Yet, though I have tried, I still have so much to learn regarding nā mea Hawai' $i$ (things Hawaiian), our 'ōlelo makuahine (mother language), our cultural practices, our histories, and even our possibilities for the future." 
Taino People across the Caribbean, too, are rebuilding their Yukayeke (community/ village), and they are re-establishing their governance systems. A most poignant example of this is the recent investiture of the Yamaye Kasike "Kalaan" Nibonrix Kaiman. This investiture ceremony after 500 plus years speaks to Taino Peoples' strength and diplomacy. It challenges the fact of being defined and categorized. It communicates that Indigenous Peoples do not have to be determined "according to contact with those who would call us 'other"' (Salis Reyes 2018 p. 740).

According to Ferbel-Azcarate and Carpinelli (n.d, p. 489), in contemporary times, Caribbean People are identifying with their Taino roots and kinship connections to their ancestors. Due to the historical circumstances, present day Taino People identities in Yamaye are multifaceted and intersectional. Importantly, Ferbel-Azcarate and Carpinelli (n.d, p. 489) state that, while many facets of contemporary Taino culture are also tied to the nation's particular history and with the combined heritage from African and European cultures, many salient themes from the common Taino past can be said to constitute a distinctive Taino identity. Therefore, it is important in the resurgence that "we do not ignore history as Indigenous people have experienced it" (Hicks 2007, p. 4). In other words, it is important to listen to Indigenous Peoples.

The United Nations Declaration on the Rights of Indigenous Peoples (UNDRIP) was adopted by the General Assembly in 2007. Jamaica was one of the countries that voted in favor of UNDRIP before many Western countries did. That was an explicit move by the government which displayed an understanding of, and the possible commitment to, a future reimagining of Indigenous rights on the Island for Indigenous Peoples there.

As I write, I share another story which involves calling my mother and the usual greeting of "how are you doing". She responded, "I am going for a walk, and I am carrying my Taino bag with me today." The Taino bag is more than just a bag because it carries memory and is identified and overtly named out loud as "my Taino bag." This is an astonishing account that has been given centuries of silencing. Naming the bag is part of remembering, knowing and ancestral affirmation. Salis Reyes (2018 p 752) sums up similar experiences in a Hawai'ian context noting "For far too long, others have tried to tell stories about who we are and where we belong."

Kasike Nibonrix Kaiman speaks of the continued work to be done. He says that it is a process and shares the following: "There's a lot being done and a lot to be done. We're working on bringing back our pottery, bringing back our ceremonies, 
bringing back our regalia, our dress, bringing back our language. Throughout the community there are groups working on these things" (BEx 2020 para 14).

Many Indigenous ways of thinking about the past do not conceive of it as 'lying behind,' but rather as being positioned 'ahead' and implicated in the 'now' (Kearney 2012 p.169). This is critical to Taino sovereignty as Indigenous Caribbean Peoples.

\section{Concluding Thoughts}

Since violence has been forced upon the lives of Indigenous People, Durán Matute (2021 p. 260) notes that Indigeneity is about community and about the means to remember community and who they are. Durán Matute suggests "strengthening... and challenging hegemonic constructions and representations..." and explains that Indigenous people do not need to accept "humiliation, exploitation, misery, and dehumanization" (2021 p. 260). For Taino people in Yamaye and elsewhere, the resurgence reflects an understanding of the Taino People as Yamaye's First Peoples, the historical circumstances, the nuances and complexities that remain today. Indigenous Peoples of the Caribbean have existed on these lands, an enacting movement through trading and building connections.

The historicity and processes of colonialism did not just happen once and then they moved on; neither is it over or complete. Rather, as Silliman (2005 p. 52) suggests, colonialism is an ongoing and diverse project that cannot be ignored in today's world, even if we consider only its extensive legacy. Meanwhile, Taino People continue to rebuild and sing their songs. Singing songs embodies our Taino peoplehood and connection in relation to their ancestors and to each other. As Cintron (2018 para 12) states, a song was the biggest gift that one could give. This worldview signifies that the Caribbean Taino ancestral lifeworld and Taino People today continue to sing and sing.

\section{References}

Archibald, J. (2008). Indigenous Storywork: Educating the Heart, Mind, Body, and Spirit. Vancouver: University of British Columbia Press.

BEx. (2020). Our people are not extinct: A reasoning with Kasike "Kalaan" Nibonrix Kaiman | Bookman Express. Retrieved September 10, 2021, from https://bookmanexpress. pub/our-people-are-not-extinct-a-reasoning-with-kasike-kalaan-nibonrix-kaiman/ 
Bogado, A. (2015, October 12). Here's the real story of Columbus that people prefer to ignore. Grist. https://grist.org/politics/heres-the-real-story-of-columbus-thatpeople-prefer-to-ignore/

Borrero, M. R. (2017). Making Peace with Atabeira in a Time of Climate Crises. Cutltural Survival Quarterly Magazine, December 2017. Retrieved September 10, 2021, from https://www.culturalsurvival.org/publications/cultural-survival-quarterly/makingpeace-atabeira-time-climate-crises

Charles, C., \& Cajete, G. A. (2020). Wisdom Traditions, Science and Care for the Earth: Pathways to Responsible Action. Ecopsychology. Volume 12, Number 2, EcopsychologyVol. 12, No. 2 https://doi.org/10.1089/eco.2020.0020

Curet, L. A. (2002). The Chief Is Dead, Long Live... Who? Descent and Succession in the Protohistoric Chiefdoms of the Greater Antilles. Ethnohistory, 49(2), 259-280. https://doi.org/10.1215/00141801-49-2-259

, C., Kiel, D., Phillips, K., Vigil, K. (n.d) Histories of Indigenous Sovereignty in Action: What is it and Why Does it Matter? | The American Historian. Retrieved September 10, 2021, from https://www.oah.org/tah/issues/2021/native-american-history-and-sovereignty/histories-of-indigenous-sovereignty-in-action-what-is-it-and-why-doesit-matter/

Durán Matute, I. (2021). Indigeneity as a transnational battlefield: disputes over meanings, spaces and peoples. Globalizations, Volume 18, Issue 21, 256-272. https:// doi.org/10.1080/14747731.2020.1771962

Ferbel-Azcarate, P. \& Carpinelli, X., A. (n.d.) Caribbean Archaeology and Taino Survival. Pp. 487-492 (n.d.). https://ufdc.ufl.edu/AA00061961/00844

Flint. V. I.J. (2019). Christopher Columbus - The fourth voyage and final years. In Encyclopedia Britannica. https://www.britannica.com/biography/Christopher-Columbus/The-fourth-voyage-and-final-years

Forte, M. C (2006). Extinction: Ideologies Against Indigeneity in the Caribbean Southern Quarterly, Hattiesburg Vol. 43, Iss. 4, (Summer 2006): 46-69.

Gardner, W. J. (2020). A History of Jamaica. In Amazon. https://www.amazon.ca/History-Jamaica-William-James-Gardner/dp/1773750771/ref=asc_ df_1773750771/?tag=googleshopc0c-20\&linkCode $=$ df0\&hvadid $=45951471997$ $7 \&$ hvpos $=\&$ hvnetw $=g \&$ hvrand $=6766049378231148745 \&$ hvpone $=\&$ hvptwo $=\&$ hvqmt $=\&$ hvdev $=c \&$ hvdvcmdl $=\&$ hvlocint $=\&$ hvlocphy $=9001077 \&$ hvtargid $=$ pla 1021042354937\&psc $=1$

Harkin, N. (2014). The Poetics of (Re)Mapping Archives: Memory in the Blood. JASAL: Journal of The Association for The Study of Australian Literature, 14(3).

Hernandez, A., Hafoka, 'Inoke, 'Ulu'ave, L., \& 'Ulu'ave-Hafoka, M. (2018). Talanoa: Tongan epistemology and Indigenous research method. AlterNative: An International Journal of Indigenous Peoples, 14(2), 156-163. https://doi.org/10.1177/1177180118767436

Henry, S., \& Woodward, R. (2019). Contact and Colonial Impact in Jamaica: Comparative Material Culture and Diet at Sevilla la Nueva and the Taíno Village of Maima. Chapter 4 in Material Encounters and Indigenous Transformations in The Early CoIonial Americas, Edited by C. L. Hofman \& F. W. M. Keehnen, pages 84-101. Brill. Accessed from https://brill.com/view/book/edcoll/9789004273689/BP000004.xml

Hicks, J. (2007) Editorial, pp. 4-6 in Indigenous Affairs IWGIA Social Suffering 4/07. Retrieved September 10, 2021, from https://www.iwgia.org/images/publications/ IA_4_07.pdf 
16 | Erica Neeganagwedgin

Caribbean Indigenous Experiences of Erasure: Movement,

Memory and Knowing

Kearney, A. (2012). Present Memories: Indigenous Memory Construct and Cross-Generational Knowledge Exchange in Northern Australian; Keightley, E. (ed). Time, media and modernity. Palgrave Macmillan.

Kennedy, R., \& Radstone, S. (2013). Memory up close: Memory studies in Australia. Memory Studies, 6(3), 237-244. https://doi.org/10.1177/1750698013486023

Koch, A., Brierley, C., Maslin, M. M., \& Lewis, S. L. (2019). Earth system impacts of the European arrival and Great Dying in the Americas after 1492. Quaternary Science Reviews, 207, 13-36. https://doi.org/10.1016/j.quascirev.2018.12.004

Neeganagwedgin, E. (2015). Rooted in the Land: Taíno identity, oral history and stories of reclamation in contemporary contexts. AlterNative: An International Journal of Indigenous Peoples, 11(4), 376-388. https://doi.org/10.1177/117718011501100405

Ortiz Cintrón. J. H. (2018, August 8). Taínos: A Culture to Remember. Medium. https:// medium.com/@viewpr/ta\%C3\%ADnos-a-culture-to-remember-b109a460880b

Porsanger J., I., Seurujärvi-Kari, \& Lydia Nystad R.(2021) "Shared Remembering" as a Relational Indigenous Method in Conceptualization of Sámi Women's Leadership. (In Kristiina Virtanen, P; Pigga Keskitalo \& T. Olsen (Eds), Indigenous Research Methodologies in Sámi and Global Contexts, 144-174. https://doi. org/10.1163/9789004463097_007

Pember, M. A. (1 C.E., November 30). Blood Memory. Daily Yonder. https://dailyyonder. com/blood-memory/2010/07/16/

Rampini, C. (1873). Letters from Jamaica, "The Land of Streams and Woods." [By Charles J.G. Rampini.]. Edinburgh.

Reyes, N. A. S. (2017). A space for survivance: locating Kānaka Maoli through the resonance and dissonance of critical race theory. Race Ethnicity and Education, 21(6), 739-756. https://doi.org/10.1080/13613324.2017.1376632

Reynoso, V. (2017). How Capitalism and Spanish Imperialism Served as a Counterrevolution to Taino Primitive Communism. Www.telesurenglish.net. Retrieved September 10, 2021, from https://www.telesurenglish.net/opinion/How-Capitalism-and-Spanish-Imperialism-Served-as-a-Counterrevolution-to-Taino-Primitive-Communism-20170712-0013.html

Santana, C. (2017). Monstrous Anthropology. Third Text, 31(4), 567-580. https://doi.org /10.1080/09528822.2017.1403754

Rousseau, M., \& Rousseau, S. (2018). Provisions: the roots of Caribbean cooking. Da Capo Press.

Santana, C. R. (n.d.). We Are Still Here: The First Taíno Movement Exhibition.

Retrieved September 10, 2021, from https://www.smithsonianmag.com/blogs/smithsonian-latino-center/2019/10/15/we-are-still-here-first-taino-movement-exhibition/

Smith, H. (2019). Whatuora: Theorizing "New" Indigenous Research Methodology from "Old" Indigenous Weaving Practice. Art/Research International: A Transdisciplinary Journal, 4(1), 1. https://doi.org/10.18432/ari29393

Linda Tuhiwai Smith. (2012). Decolonizing methodologies: research and indigenous peoples. Zed Books.

Silliman, S. W. (2005). Culture Contact or Colonialism? Challenges in the Archaeology of Native North America. American Antiquity, 70(1), 55-74. https://doi. org/10.2307/40035268

Strecker, A. (2016). Revival, Recognition, Restitution: Indigenous Rights in the Eastern Caribbean. International Journal of Cultural Property, 23(2), 167-190. https://doi. org/10.1017/s0940739116000096 
United Nations. (2007). United Nations Declaration on the Rights of Indigenous Peoples. Human Rights Quarterly, 33(3), 909-921. https://doi.org/10.1353/ hrq.2011.0040

Vizenor. R. (1999). Manifest manners: postindian warriors of survivance. Wesleyan University Press.

Wesley-Esquimaux, C. (2007). The intergenerational transmission of Historic Trauma and Grief. Pp. 6-12. In Indigenous Affairs IWGIA Social Suffering 4/7. Retrieved September 10, 2021, from https://www.iwgia.org/images/publications/IA_4_07.pdf

Yelvington, A. K. (2000). Caribbean Crucible: History, Culture, and Globalization (2000). https://www.socialstudies.org/sites/default/files/publications/se/6402/640201. $\mathrm{html}$ 